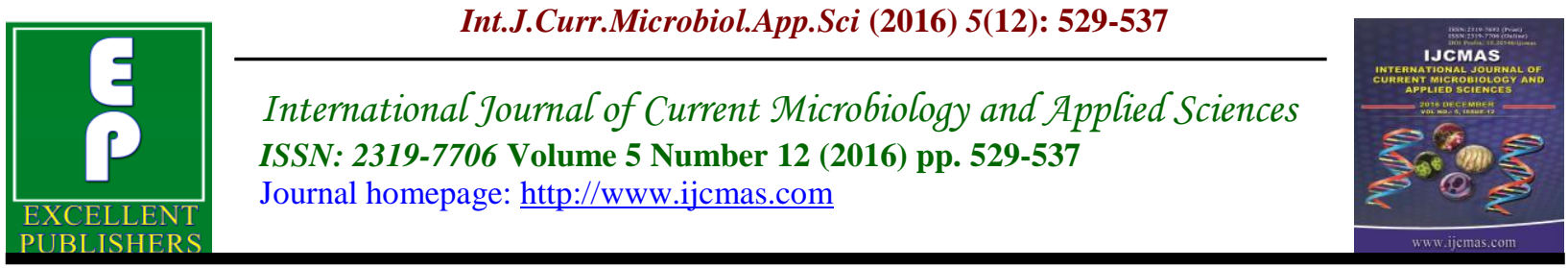

Original Research Article

http://dx.doi.org/10.20546/ijcmas.2016.512.058

\title{
Prevalence of Enteric Parasites among HIV Seropositive Patients and Co-Relation with CD4 T Cell Count
}

\author{
Nagesh Vithalrao Abdagire*, V.V. Chincholkar, S.L. Nilekar and S.R. More \\ No-2, S.R.T.R. Govt. Medical College, Ambajogai, Dist. Beed, India \\ *Corresponding author:
}

\begin{tabular}{l} 
Ke y w o r d s \\
HIV, \\
Diarrhoea, \\
Cd4 Count, \\
Coccidian \\
Parasites. \\
\hline Article Info \\
\hline Accepted: \\
18 November 2016 \\
Available Online: \\
10 December 2016
\end{tabular}

\section{A B S T R A C T}

Human immunodeficiency Virus (HIV) infection is a global pandemic, with cases reported virtually from every country. In HIV infected patients, a progressive decline in their immunological responses makes them extremely susceptible to a variety of common and opportunistic infections. Intestinal parasitic infection remains as an important cause of morbidity and mortality in developing countries. Presently, CD4 T cell count has been shown to be an excellent indicator which defines the degree of an immune suppression. Diarrhoea and intestinal parasitic infections are strongly associated with low CD4 T cell count. Therefore the present study was undertaken to determine the prevalence of enteric parasites affecting the HIV seropositive patients with and without diarrhoea. An attempt was also made to evaluate the association between CD4 $\mathrm{T}$ cell count and presence of enteric parasites. A total of $510 \mathrm{HIV}$ seropositive patients were included in the study. Microscopic examination was done by direct saline and iodine mount. Smears were prepared to identify the coccidian parasites by using modified ZiehlNeelsen stain. All the specimens were subjected to sedimentation and floatation technique for concentration of parasitic ova and cysts. Sheather's sugar floatation technique was performed for detection of coccidian parasites. Estimation of CD4/CD8 count was done by automated flowcytometer analyzer (BD FACS). Out of 510 HIV seropositive patients, intestinal parasites were detected in $132(25.88 \%)$ cases and most commonly observed intestinal parasite was Cryptosporidium parvum followed by Isospora belli and least commonly observed parasites were Hymenolepis nana and Taenia spp. The maximum incidence of diarrhoea was seen among patients with CD4 T cell count less than 200 cells / $\mu 1$. Also, the detection rate of intestinal parasites was more in patients presented with diarrhoea having CD4 T cell count less than 200 cells / $\mu$ l. The detection of intestinal parasites in HIV seropositive patients will help in proper management of these patients as drugs are available for the treatment of most of the infections. Hence, routine screening of the stool samples of HIV seropositive patients with and without diarrhoea should be done for prompt patient care, to prevent the fulminant form of the disease.

\section{Introduction}

Human immunodeficiency Virus (HIV) infection is a global pandemic, with

cases reported virtually from every
country $\quad$ (Fauci, 2008). $\begin{aligned} & \text { Human } \\ & \text { Immunodeficiency Virus has }\end{aligned}$


major challenge to public health in the present time (UNAIDS, 2013). India is estimated to have the third largest HIV positive population in the world. Ever since HIV was found in Chennai in 1986, India has had an Acquired Immune-Deficiency Syndrome (AIDS) epidemic. The total number of people living with HIV/AIDS (PLHIV) in India is estimated to be around 20.9 lakh in 2011 with 1.16 lakh new HIV infections (Annual report, 2013-14).

In HIV infected patients, a progressive decline in their immunological responses makes them extremely susceptible to a variety of common and opportunistic infections. The gastrointestinal involvement in HIV/AIDS is almost universal, and a significant disease occurs in $50-90 \%$ of the patients while diarrhoea can be a presenting manifestation or life threatening complication in HIV seropositive patients. Intestinal parasitic infection remains as an important cause of morbidity and mortality in developing countries (Zali et al., 2004).

Presently, CD4 T cell count has been shown to be an excellent indicator which defines the degree of an immune suppression. Diarrhoea and intestinal parasitic infections are strongly associated with low CD4 T cell count (Zali et al., 2004). The outcome of infection by enteric protozoan parasites is dependent on absolute $\mathrm{CD}^{+}{ }^{+} \mathrm{T}$ cells counts, with lower counts being associated with more severe and atypical disease (Stark et al., 2007).

The detection of these parasites will help in proper management of these patients as drugs are available for the treatment of most of the infections. There appears to be a scarcity of data on correlation of CD4 T cell counts and the aetiology of diarrhoea among the HIV seropositive patients in this part of India. Therefore the present study was undertaken to determine the prevalence of enteric parasites affecting the HIV seropositive patients with and without diarrhoea. An attempt was also made to evaluate the association between CD4 T cell count and presence of enteric parasites.

The main aim and objectives of this study includes, to study the prevalence of intestinal parasitic infections among HIV seropositive patients. To study the distribution of intestinal parasites among symptomatic \& asymptomatic HIV seropositive cases. And also to study the correlation of intestinal parasitic infections with CD4 T cell count.

\section{Materials and Methods}

The present study was conducted in the Department of Microbiology at S. R. T. R. Govt. Medical College Ambajogai for period of two years from Oct. 2012 to Sep. 2014. Ethical clearance from institutional ethical committee was obtained.

A total of 510 HIV seropositive patients were included in the study. HIV seropositive patients, who had received antiparasitic treatment for diarrhoea in past 3 weeks, were excluded from study. Stool specimens were collected in wide mouthed, clean, dry, plastic containers with tight fittings lids. No attempt was made to isolate bacteria and viruses.

The specimens were examined by naked eye for colour, consistency, presence of blood, mucus and adult or segments of worms. Microscopic examination was done by direct saline and iodine mount. Smears were prepared to identify the coccidian parasites by using modified Ziehl-Neelsen stain and examined with oil immersion objective. All the specimens were subjected to formol ether centrifugal sedimentation technique 
and Zinc sulphate centrifugal floatation technique for concentration of parasitic ova and cysts. Sheather's sugar floatation technique was performed for detection of coccidian parasites.

About $5 \mathrm{ml}$ of venous blood was collected from all patients in a vacutainer containing K2 EDTA for estimation of CD4/CD8 count by automated flow cytometer analyzer (BD FACS). The patients were categorised by their immune status according to the 1993 revised classification system for the HIV infection by CD4 T-cell categories (WHO, 2007). The data obtained was analyzed by applying appropriate statistics wherever needed.

\section{Result and Discussion}

Among 510 HIV seropositive patients screened in the present study, 270 (52.94\%) were presented with diarrhoea and 240 (47.06\%) were non diarrhoeal. Maximum numbers of the patients were seen in the age group of 31-40 years and maximum diarrhoeal cases were seen in age above 50 years. Among all the patients, males $(54.12 \%)$ were more as compared to females $(45.88 \%)$ but the incidence of diarrhoea was more among females $(66.67 \%)$.

Out of 510 HIV seropositive patients, intestinal parasites were detected in 132 (25.88\%) cases amongst which, 104 were presented with diarrhoea and 28 were non diarrhoeal. Detection of intestinal parasites significantly higher among HIV seropositive patients with diarrhoea than those without diarrhoea.

A total of 149 intestinal parasites were isolated from 132 patients of which 116 cases were single parasitic infection and 16 showed mixed infections. The combination of Cryptosporidium parvum and Isospora belli was most frequently observed. In our study, most commonly observed intestinal parasite was Cryptosporidium parvum followed by Isospora belli and least commonly observed parasites were Hymenolepis nana and Taenia spp.

When we see the co- relation of CD4 $\mathrm{T}$ cell count with diarrhoea, the maximum incidence of diarrhoea was seen among patients with CD4 $\mathrm{T}$ cell count less than 200 cells / $\mu 1$. Also, the detection rate of intestinal parasites was more in patients presented with diarrhoea having CD4 $\mathrm{T}$ cell count less than 200 cells / $\mu$ l.

Acquired immunodeficiency syndrome (AIDS) ranks among the most dreaded diseases affecting mankind, causing dysfunction of both limbs of the immune system, resulting in overwhelming and fatal opportunistic infections. Gastrointestinal involvement primarily in the form of diarrhoea is a universal problem affecting almost $90 \%$ of HIV infected patients in developing countries. The etiological spectrum of the enteric pathogens which cause diarrhoea includes bacteria, parasites, fungi and viruses (Sachin et al., 2011). The parasites can cause self-limiting diarrhoea of short duration in healthy individuals, but in the immunocompromised host including AIDS patients, the diarrhoea is usually chronic and sometimes, life-threatening. The coccidian parasites are foremost among the enteric parasites in HIV seropositive patients with diarrhoea. Diarrhoea and intestinal parasitic infections are strongly associated with low CD4 T cell count (Tabaseera et al., 2012).

In the present study, 510 HIV seropositive patients were screened for intestinal parasites amongst which, 270 (52.94\%) were presented with diarrhoea and 240 $(47.06 \%)$ were non diarrhoeal. 
The present study has maximum cases in age group of 31-40 years followed by 21-30 years. Similarly Sachin Deorukhkar et al., Naik et al., Kotgire et al., had maximum cases in age group of 31-40 followed by 2130 years. Maximum incidence of diarrhoea among HIV seropositive patients was seen in age above 50 years. Similarly Dwivedi et al., showed the maximum incidence of diarrhoea above 45 years of age whereas Sachin Deorukhkar et al., and Raytekar et al., and Malaji et al., found maximum diarrhoeal patients in the age group of 31-40 years.

In the present study, among 510 HIV seropositive patients, males $(54.12 \%)$ were more as compared to females $(45.88 \%)$, however incidence of diarrhoea was more among females as compared to males. Similar observation was seen in other studies also (Sachin et al., 2011).

In the present study, out of 510 HIV seropositive patients $161(31.57 \%)$ had $\mathrm{CD}_{4}$ $\mathrm{T}$ cell count $<200$ cells $/ \mu 1$. Maximum incidence of diarrhoea was seen among patients with $\mathrm{CD}_{4} \mathrm{~T}$ cell count $<200$ cells $/ \mu 1$. (113/161, 70.19\%). These findings were comparable with study done by Nazeema et al., (76,4\%) and Tiwari et al., (60.24\%). Diarrhoea is one of the most common manifestations in HIV patients and is strongly associated with low $\mathrm{CD}_{4} \mathrm{~T}$ cell counts.

In the present study, prevalence of intestinal parasites among HIV seropositive patients was $25.88 \%(132 / 510)$. The results comparable to our study were shown by Mehta et al., Gupta et al., Gupta et al., and Mohandas et al., while Babatunde et al., Dwivedi et al., and Basak et al., have documented higher prevalence. The prevalence of intestinal parasitic infections among HIV seropositive patients ranged from $17.3 \%$ to $87.8 \%$ in different parts of the world. The difference in the pattern of prevalence of intestinal parasites seen in the present study and others may be attributed to the regional variability (demographic and ecological factors) of the pathogen, behavioural activities, the diagnostic method used, asymptomatic shedding of oocysts and the use of prophylactic drugs etc.

In the present study, the prevalence of the intestinal parasites among HIV seropositive patients with diarrhoea was higher (42.96\%) and statistically significant than patients without diarrhea (13.75\%). Similar to our study, others also showed higher parasitic prevalence among HIV seropositive diarrhoeal patients as compared to non diarrhoeal cases.

In this study found single parasitic infection in 116 patients and mixed infections in $16(3.14 \%)$ cases. Mixed infections is a common observation in areas where various types of parasites are prevalent and also due to poor hygienic practices.

Our study projects cryptosporidium parvum $(10.98 \%)$ as the most common coccidian parasite which was associated with HIV seropositive patients. Other studies from India also reported Cryptosporidium parvum to be the most common parasite isolated from HIV seropositive patients (Basak et al., 2010; Venkateshswarlu et al., 2013; Vyas et al., 2013). In India prevalence of Isospora belli varies from $2.5 \%$ to $50 \%$. In our study, prevalence of Isospora belli was $4.31 \%$.

The prevalence of Cryptosporidium parvum in HIV seropositive patients in different parts of the India has ranged from $0.7-87 \%$ in symptomatic patients and from $1.4-57 \%$ in asymptomatic individuals (Vyas et al., 2013). In our study, difference in prevalence of Cryptosporidium parvum \& Isospora belli in diarrhoeal patients was statistically significant as compared to non diarrhoeal 
patients. Similar findings were reported by Sachin Deorukhkar et al., Nazeema et al., and Naik et al., (2005).

In our study, detection rate of intestinal parasites among HIV seropositive patients with CD4 T cell count $<200$ cells/ $\mu$ l was $63.35 \%$ which was significantly higher than other two groups (Table No.6) Mehta et al., had also reported $67.70 \%$ detection rate of intestinal parasites in patients with CD4 T cell count $<200$ cells/ $\mu$ l which is comparable to our finding. Sow et al., found a higher $(86.6 \%)$ detection rate than ours, Whereas Tiwari et al., (42.81\%), Kulkarni et al., (46\%) and Nazeema et al., $(47.06 \%)$ showed a somewhat lower detection rate of intestinal parasites in patients with CD4 T cell count $<200$ cells/ $\mu 1$ than our study.

Cellular immunity is the major defence against intestinal parasitic infections; it is therefore, the reduction in CD4 $\mathrm{T}$ cell count predisposes HIV infected patients to opportunistic intestinal parasitic infections. ${ }^{27}$ Presently, CD4 T cell count has been an excellent indicator which defines the degree of immune suppression.

The variation in the prevalence of intestinal parasitic infection demonstrated in different studies can be attributed to the difference in geographical distribution of parasites, awareness of hygiene, availability of medical facilities and different selection of cases. This variation may also be pertaining to the infectivity of parasites at different level of immunosupression. In our study, significant numbers of intestinal parasites were also seen in HIV seropositive patients without diarrhoea thus indicating that there may be asymptomatic infections which may be going undiagnosed, thereby increasing the morbidity and mortality which are associated with them.

Table.1 Age wise distribution of HIV seropositive patients with and without diarrhea

\begin{tabular}{|c|c|c|c|}
\hline Age (years) & With Diarrhoea & Without Diarrhoea & Total \\
\hline $0-10$ & $24(57.14 \%)$ & $18(42.86 \%)$ & $\mathbf{4 2}$ \\
\hline $11-20$ & $6(17.14 \%)$ & $29(82.86 \%)$ & $\mathbf{3 5}$ \\
\hline $21-30$ & $68(58.62 \%)$ & $48(41.38 \%)$ & $\mathbf{1 1 6}$ \\
\hline $31-40$ & $93(50.82 \%)$ & $90(49.18 \%)$ & $\mathbf{1 8 3}$ \\
\hline $41-50$ & $51(54.26 \%)$ & $43(45.74 \%)$ & $\mathbf{9 4}$ \\
\hline$>50$ & $28(70.00 \%)$ & $12(30.00 \%)$ & $\mathbf{4 0}$ \\
\hline Total & $\mathbf{2 7 0}(\mathbf{5 2 . 9 4 \%})$ & $\mathbf{2 4 0}(\mathbf{4 7 . 0 6 \%})$ & $\mathbf{5 1 0}$ \\
\hline
\end{tabular}

Table.2 Sex wise distribution of HIV seropositive patients with and without diarrhea

\begin{tabular}{|c|c|c|c|}
\hline Sex & With Diarrhoea & Without Diarrhoea & Total \\
\hline Male & $114(41.30 \%)$ & $162(58.70 \%)$ & 276 \\
\hline Female & $156(66.67 \%)$ & $78(33.33 \%)$ & 234 \\
\hline Total & $\mathbf{2 7 0}(\mathbf{5 2 . 9 4 \% )}$ & $\mathbf{2 4 0}(\mathbf{4 7 . 0 6 \% )}$ & $\mathbf{5 1 0}$ \\
\hline
\end{tabular}


Table.3 Distribution of CD4 T cell count among HIV seropositive patients with and without diarrhea

\begin{tabular}{|c|c|c|c|}
\hline CD $_{\mathbf{4}}$ T cells $/ \boldsymbol{\mu l}$ & With Diarrhoea & Without Diarrhoea & Total \\
\hline$<\mathbf{2 0 0}$ cells $/ \boldsymbol{\mu l}$ & $113(70.19 \%)$ & $48(29.81 \%)$ & $\mathbf{1 6 1}$ \\
\hline $\mathbf{2 0 0 - 5 0 0}$ cells $/ \boldsymbol{\mu l}$ & $54(44.26 \%)$ & $68(55.74)$ & $\mathbf{1 2 2}$ \\
\hline$>\mathbf{5 0 0}$ cells $/ \boldsymbol{\mu l}$ & $103(45.37 \%)$ & $124(54.63 \%)$ & $\mathbf{2 2 7}$ \\
\hline Total & $\mathbf{2 7 0}(\mathbf{5 2 . 9 4 \%})$ & $\mathbf{2 4 0}(\mathbf{4 7 . 0 6 \%})$ & $\mathbf{5 1 0}$ \\
\hline \multicolumn{4}{|r}{} \\
\hline
\end{tabular}

Table.4 Prevalence of intestinal parasites among HIV seropositive patients with and without diarrhoea: $(n=510)$

\begin{tabular}{|c|c|c|c|}
\hline \multirow{2}{*}{$\begin{array}{c}\text { Intestinal } \\
\text { parasites }\end{array}$} & With Diarrhoea & Without Diarrhoea & \multirow{2}{*}{ Total } \\
\cline { 2 - 4 } Positive & $104(20.39 \%)$ & $28(05.49 \%)$ & $\mathbf{1 3 2}(\mathbf{2 5 . 8 8})$ \\
\hline Negative & $166(32.55 \%)$ & $212(41.57)$ & $\mathbf{3 7 8}(\mathbf{7 4 . 1 2})$ \\
\hline Total & $270(52.94 \%)$ & $240(47.06 \%)$ & $\mathbf{5 1 0}(\mathbf{1 0 0})$ \\
\hline \multicolumn{3}{|c|}{$\mathrm{X}^{2}=47.756, \mathrm{df}=1$; significant at $\mathrm{P}<0.05$} \\
\hline
\end{tabular}

Table.5 Distribution of intestinal parasites among HIV seropositive patients with and without diarrhea

\begin{tabular}{|c|l|l|l|l|l|}
\hline Intestinal parasites & $\begin{array}{c}\text { With diarrhoea } \\
(\mathbf{n = 2 7 0})\end{array}$ & $\begin{array}{c}\text { Without } \\
\text { diarrhoea } \\
(\mathbf{n = 2 4 0})\end{array}$ & $\begin{array}{c}\text { Total } \\
(\mathbf{n = 5 1 0})\end{array}$ & Z stat & P value \\
\hline Intracellular Protozoans & & & & & \\
\hline Cryptosporidium parvum & $50(18.52 \%)$ & $06(02.50 \%)$ & $\mathbf{5 6}$ & $5.77 *$ & $<0.001$ \\
\hline Isospora belli & $19(07.04 \%)$ & $03(1.25 \%)$ & $\mathbf{2 2}$ & $3.21 *$ & 0.00132 \\
\hline Extracellular Protozoans & & & & & \\
\hline Entamoeba histolytica & $14(05.18 \%)$ & $06(02.50 \%)$ & $\mathbf{2 0}$ & 1.55 & 0.1187 \\
\hline Giardia Lamblia & $09(03.33 \%)$ & $04(1.67 \%)$ & $\mathbf{1 3}$ & 1.92 & 0.234 \\
\hline Helminths & & & & & \\
\hline Ancylostoma duodenale & $09(03.33 \%)$ & $02(0.83 \%)$ & $\mathbf{1 1}$ & 1.939 & 0.0523 \\
\hline Ascaris lumbricoides & $06(02.22 \%)$ & $05(02.08 \%)$ & $\mathbf{1 1}$ & 0.1078 & 0.9124 \\
\hline Strongyloides stercoralis & $07(02.59 \%)$ & $03(1.25 \%)$ & $\mathbf{1 0}$ & 1.091 & 0.2757 \\
\hline Hymenolepis nana & $01(0.37 \%)$ & $02(0.83 \%)$ & $\mathbf{0 3}$ & -0.682 & 0.496 \\
\hline Taenia spp. & & & & & \\
\hline Total & $01(0.37 \%)$ & $02(0.83 \%)$ & $\mathbf{0 3}$ & -0.682 & 0.496 \\
\hline
\end{tabular}

$* \mathbf{P}<0.05$, significant 
Table.6 Parasite detection in relation to CD4 T cell count:

\begin{tabular}{|c|c|c|c|}
\hline $\mathbf{C D}_{\mathbf{4}} \mathbf{T}$ cells $/ \boldsymbol{\mu l}$ & Parasite positive & Parasite negative & Total \\
\hline$<\mathbf{2 0 0}$ cells/ $\boldsymbol{\mu} \mathbf{l}$ & $102(63.35 \%)$ & $59(36.65 \%)$ & 161 \\
\hline $\mathbf{2 0 0 - 5 0 0}$ cells/ $\boldsymbol{\mu l}$ & $21(17.21 \%)$ & $101(82.79 \%)$ & 122 \\
\hline$>\mathbf{5 0 0}$ cells/ $\boldsymbol{\mu l}$ & $09(3.96 \%)$ & $218(96.04 \%)$ & 227 \\
\hline Total & $\mathbf{1 3 2}$ & $\mathbf{3 7 8}$ & $\mathbf{5 1 0}$ \\
\hline \multicolumn{4}{|r|}{} \\
\hline
\end{tabular}

Table.7 Distribution of intestinal parasites in relation to CD4 T cell count

\begin{tabular}{|c|c|c|c|c|c|c|c|}
\hline \multirow[t]{2}{*}{$\begin{array}{l}\text { Intestinal } \\
\text { parasites }\end{array}$} & \multicolumn{2}{|c|}{$\begin{array}{c}\text { CD4<200 cells/ } \mu \mathrm{l} \\
\mathrm{N}=161\end{array}$} & \multicolumn{2}{|c|}{$\begin{array}{c}\text { CD4 200-500 cells/ } \mu \mathrm{l} \\
\mathrm{N}=122\end{array}$} & \multicolumn{2}{|c|}{$\begin{array}{c}\text { CD4>500 cells } / \mu \mathrm{l} \\
\mathrm{N}=227\end{array}$} & \multirow[t]{2}{*}{ Total } \\
\hline & $\begin{array}{c}\text { Diarrhoeal } \\
(\mathrm{N}=113)\end{array}$ & $\begin{array}{c}\text { Non } \\
\text { Diarrhoeal } \\
(\mathrm{N}=48)\end{array}$ & $\begin{array}{c}\text { Diarrhoeal } \\
(\mathbf{N}=54)\end{array}$ & $\begin{array}{c}\text { Non } \\
\text { Diarrhoeal } \\
(\mathbf{N}=68)\end{array}$ & $\begin{array}{c}\text { Diarrhoeal } \\
(\mathrm{N}=103)\end{array}$ & $\begin{array}{c}\text { Non } \\
\text { Diarrhoeal } \\
(\mathrm{N}=124)\end{array}$ & \\
\hline $\begin{array}{l}\text { Cryptosporidium } \\
\text { parvum }\end{array}$ & 45 & 06 & 03 & 00 & 02 & 00 & 56 \\
\hline Isospora belli & 15 & 03 & 03 & 00 & 01 & 00 & 22 \\
\hline $\begin{array}{l}\text { Entamoeba } \\
\text { histolytica }\end{array}$ & 11 & 04 & 01 & 01 & 02 & 01 & 20 \\
\hline Giardia lamblia & 06 & 03 & 01 & 01 & 02 & 00 & 13 \\
\hline $\begin{array}{l}\text { Ancylostoma } \\
\text { duodenale }\end{array}$ & 06 & 01 & 02 & 01 & 01 & 00 & 11 \\
\hline $\begin{array}{l}\text { Ascaris } \\
\text { lumbricoides }\end{array}$ & 04 & 03 & 02 & 02 & 00 & 00 & 11 \\
\hline $\begin{array}{l}\text { Strongyloides } \\
\text { stercoralis }\end{array}$ & 05 & 01 & 02 & 02 & 00 & 00 & 10 \\
\hline Hymenolepis nana & 01 & 00 & 00 & 01 & 00 & 01 & $\mathbf{0 3}$ \\
\hline Taenia spp. & 00 & 00 & 01 & 02 & 00 & 00 & $\mathbf{0 3}$ \\
\hline Total & 93 & 21 & 15 & 10 & 08 & 02 & 149 \\
\hline
\end{tabular}

Therefore the detection of intestinal parasites in HIV seropositive patients will help in proper management of these patients as drugs are available for the treatment of most of the infections. Hence, routine screening of the stool samples of all HIV seropositive patients with and without diarrhoea should be done for prompt patient care, to prevent the fulminant form of the disease.

In conclusion, HIV infected patients, a progressive decline in their immunological responses makes them extremely susceptible to a variety of common and opportunistic infections. The gastrointestinal involvement in HIV infection is almost universal, and a significant disease occurs in $50-90 \%$ of the patients while diarrhoea can be a presenting manifestation or life threatening complication in HIV seropositive patients. Intestinal parasitic infestation remains as an important cause of morbidity and mortality in developing countries. 
The detection of intestinal parasites in HIV seropositive patients will help in proper management of these patients as drugs are available for the treatment of most of the infections. Hence, routine screening of the stool samples of HIV seropositive patients with and without diarrhoea should be done for prompt patient care, to prevent the fulminant form of the disease.

\section{References}

Annual report. 2013-14 [Internet]. New Delhi; 2013 p. 1. Available from: www.naco.gov.in

Babatunde, S.K., Salami, A.K., Fabiyi, J.P., Agbede, O.O., Desalu, O.O. 2010. Prevalence of intestinal parasitic infestation in HIV seropositive and seronegative patients in Ilorin, Nigeria. Ann. Afr. Med., 9(3): 123-8.

Basak, S., Bose, S., Mallick, S.K., Ghosh, A.K. 2010. Intestinal Parasitic Infections In HIV Seropositive Patients, J. Clin. Diagn. Res., 2433-7.

Dwivedi, K.K., Prasad, G., Saini, S., Mahajan, S., Lal, S., Baveja, U.K. 2007. Enteric Opportunistic Parasites among HIV Infected Individuals : Associated Risk Factors and Immune Status. Jpn J. Infect. Dis., 60: 76-81.

Fauci, S.A. 2008. Human Immunodeficiency Virus Disease: AIDS and related disease. In: Kasper LD, Braunwald E, Fauci SA, Hauser SL, Lango DL JL, editor. Harrison's Principle of Internal Medicine. 17 th. New York: Mc Graw-Hill Medical Publishing Divison, p. 1506-87.

Gupta, M., Sinha, M., Raizada, N. 2008. Opportunistic Intestinal Protozoan Parasitic Infection in HIV Positive Patient in Jamnagar, Gujarat. SAARC J. Tuberc. Lung Dis. HIV/AIDS. 1: 14.
Gupta, S., Narang, S., Nunavath, V., Singh, S. 2008. Diarrhoea In HIV Patients: Prevalence Of coccidian Parasites. Indian J. Med. Microbiol., 26(2): 1725.

Kulkarni, S.V., Kairon R, Sane SS, Padmawar PS, Kale V, Thakar MR, et al. Opportunistic parasitic infections in HIV/AIDS patients presenting with diarrhoea by the level of immunesuppression. Indian J. Med. Res., 130(1): 63-6.

Malaji, S.M., Bajaj, G., S.A. Kora., Chikkamath., Renuprasad. Study of opportunistic parasitic infections at various level of immunosuppression in HIV /AIDS patients presenting with diarrhoea. J. Pharm. Biomed. Sci., 20(10): 18-20.

Mehta, K.D., Vacchani, A., Mistry, M.M., Kavathia, G.U., Goswami, Y.S. 2013. To Study the Prevalence of Various Enteric Parasitic Infections Among HIV Infected Individuals in the P.D.U. Medical College and Hospital, Rajkot, Gujarat, India. J. Clin. Diagn. Res., 7(1): 58-60.

Mohandas, K., Sehgal, R., Sud, A., Malla, N. 2002. Prevalence of Intestinal Parasitic Pathogens in HIVSeropositive Individuals in Northern India. Jpn J. Infect. Dis., 75: 83-4.

Mohanty, I., Panda, P., Sahu, S., Dash, M. 2013. Prevalence of isosporiasis in relation to CD4 cell counts among HIV-infected patients with diarrhea in Odisha, India. Adv. Biomed. Res., 2(61).

Naik, R.V., Ravichandraprakash, H., Vijatyanath, V. 2012. Opportunistic Intestinal parasitic Infections In HIV/AIDS Patients Presenting With Diarrhoea and Their Correlation With CD4 T Lymphocyte Counts. Int. J. Pharm. Biol. Sci., 2(4): 293-9. 
Okodua, M., Age, H.O. 2003. Age and Sex Distribution of Intestinal Parasitic Among HIV Infected Subjects in Abeokuta, Nigeria. Online J. Heal Allied Sci., 2(4): 1-5.

Raytekar, N.A., Saini, S., Deorukhkar, S. 2012. Intestinal Parasitic Prevalence in HIV Infected Patients With \& Without Diarrhoea and Its Association With CD4 $\mathrm{T}$ cells Counts. Int. J. Biomed. Adv. Res., 3(11): 853-7.

Sachin, D., Ruchi, K., Santosh, S. 2011. The Prevalence of Intestinal Parasitic Infections in HIV Infected Patients in a Rural Tertiary Care Hospital of Western Maharashtra, A 5 year study, J. Clin. Diagn. Res., 5(2): 210-2.

Santosh, K., Nilima, T. Evaluation of Parasite Causing GIT ( Gastrointestinal Tract ) Iinfestations in HIV / AIDS Patients. Int. J. Basic Appl. Med. Sci., 1(1): 61-5.

Sherchan, J.B., Ohara, H., Sakurada S, Basnet A, Tandukar S. 2012. Enteric Opportunistic Parasitic Infections Among HIV- Seropositive Patients in Kathmandu, Nepal. Kathmandu Univ. Med. J., 38(2): 14-7.

Sow, P., Coume, M. 2012. About Intestinal Parasitic Infections in a Cohort of HIV-Infected Patients. Adv. Biores., 3(2): 32-5.

Stark, D., Barratt, J.L.N., Vanhal, S., Marriott, D., Harkness, J., Ellis, J.T. 2009. Clinical significance of enteric Protozoa in the Immunosupressed Human population. Clin. Microbiol. Rev., 22(4): 634-50.
Tabaseera, N., Anuradha, K., Venkatesha, D. 2012. Diarrhea, CD4 Cell Counts and Intestinal Parasitic Infection in HIV Seropositive Patients in a Tertiary Care Hospital. Int. J. Heal Sci. Res., (5): 17-23.

Tiwari, B.R., Ghimire, P., Malla, S., Sharma, B., Karki, S. 2013. Intestinal parasitic infection among the HIVinfected patients in Nepal. J. Infect. Dev. Ctries., 7(7): 550-5.

UNAIDS report on the global AIDS epidemic, Geneva; 2013.

Venkateshswarlu, K., Bai, K., Bala, K. A study of enteric parasitic infections in HIV/AIDS and HIV sero negative individuals in population of Khammam district. Int. J. Med. Res. Heal. Sci., (3): 514.

Vyas, N., Sood, S., Sharma, B. 2013. The Prevalence of Intestinal Parasitic Infestation and the Related Profile of the CD 4 + Counts in HIV / AIDS People with Diarrhoea in Jaipur City. J. Clin. Diagn. Res., 7(3): 454-6.

WHO. 2007. Case Definations of HIV for Surveilance and Revised Clinical Stagining and Immunological Classification of HIV-Related Disease in Adults and Children, Geneva, p. 15.

Zali, M.R., Mehr, A.J., Rezaian, M., Meamar, A.R., Vaziri, S., Mohraz, M. 2004. Prevalence of Intestinal Parasitic Pathogens among HIV-Positive Individuals in Iran. Jpn J. Infect. Dis., 57: $268-70$.

\section{How to cite this article:}

Nagesh Vithalrao Abdagire, V.V. Chincholkar, S.L. Nilekar and S.R. More. 2016. Prevalence of Enteric Parasites among HIV Seropositive Patients and Co-Relation with CD4 T Cell Count. Int.J.Curr.Microbiol.App.Sci. 5(12): 529-537. doi: http://dx.doi.org/10.20546/ijcmas.2016.512.058 